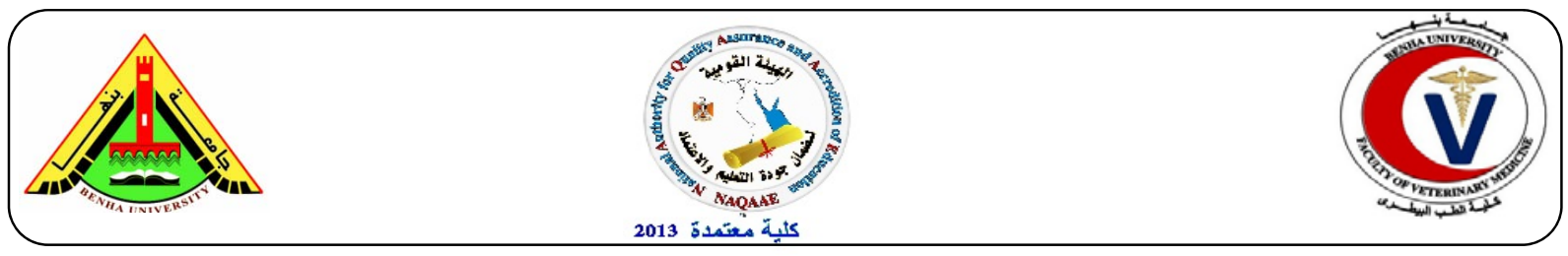

\title{
Pathological study on the effect of some food additives in male albino rats
}

\author{
Alaa N.A. AL-Sharkawy ${ }^{1,2}$, Mahmoud S. Gab-Allah ${ }^{1}$, Abdel-Baset I. El-Mashad ${ }^{1}$ and Dalia F. \\ Khater ${ }^{2}$. \\ 1. Department of Pathology, Faculty of Veterinary Medicine, Benha University. ${ }^{2}$. Animal Health Research Institute, \\ Tanta lab.
}

\section{A B S T R A C T}

The histo and clinicopathological effect of MonoSodium Glutamate (food enhancer) and Sodium MetaBisulfite (food preservatives) on different tissues and organs of male Albino rats were investigated. Eighty male Albino rats (150-180 gm) were divided into 5 groups: control group and 4 groups administrated 30 and $60 \mathrm{mg}$ MSG $/ \mathrm{kg}$ b.wt; 260 and $520 \mathrm{mg} \mathrm{SMB} / \mathrm{kg}$ b.wt for 12 weeks per os. Rats were sacrificed at 2, 4, 8 and 12 weeks from beginning the experiment. Significant decrease in $\mathrm{Hb}$ concentration, PCV, MCV and MCH; and significant increase in RBCs, leukogram, platelet counts, GPT, GOT, BUN, creatinine and total protein were observed in rats administred 30 and $60 \mathrm{mg}$ MSG $/ \mathrm{kg}$ b.wt. Histopathologically, mild changes were observed in liver, kidney, heart, stomach and intestine. Multifocally, marked degenerative and necrotic changes were seen in the lining epithelium of the seminiferous tubules and neurons particularly in high doses after 8 and 12 weeks post MSG administration. On the other hand, administration of SMB by a dose 260 and $520 \mathrm{mg} / \mathrm{kg}$ b.wt resulted in significant increase in $\mathrm{Hb}, \mathrm{MCH}, \mathrm{MCHC}$, Platelets, total leukocytic counts, GPT, GOT, albumin, BUN and creatinine values. Microscopically, hyperplasia of the biliary epithelium, lymphoid depletion of white pulpe of the spleen and mild degenerative changes in the lining epithelium of the seminiferous tubules, neurons and cardiac muscle were detected. Moderate changes were seen in the renal tissue characterized by degenerative changes in the endothelial cells of glomeruli and renal tubular epithelium with desquamation of the lining epithelial cells and presence of hyaline casts in the lumen. Multifocally, necrotic gastroenteritis with heavy leukocytic infiltration in the lamina propria of the stomach and intestine. In conclusion, the addition of MSG resulted in marked changes in brain and testes while, SMB lead to marked changes in gastrointestinal tract and brain. These changes are dose and time independent in MSG and dose independent only in SMB.

Keywords: MSG, SMB, Food enhancer, Food preservatives.

(http://www.bvmj.bu.edu.eg)

(BVMJ-33(2): 75-87, DECEMBER, 2017)

\section{INTRODUCTION}

Food additives are widely used to preserve the quality of the food, to achieve the uniformity needed for large-scale production, to enhance the flavor, or to improve the texture of a food product (Mahindru 2004). One of the most common food additives used all over the world is flavor enhancer called Monosodium glutamate (MSG) which is a sodium salt of naturally occurring (non- essential) L-form of glutamic acid, (Obaseiki et al, 2003). Ingestion of high concentration of MSG causes the appearance of neurological diseases, mainly Parkinson and Alzheimer (Arruda et al, 2003). Glutamate in high doses produce neuroendocrine abnormalities and neuronal degeneration (Moreno et al., 2005), and oxidative damage in different organs. There are some reports of the toxic effects of MSG on the liver and kidney (Nwaopara et al., 2008 a). Glutamate receptors are present in the liver, lung, kidney, spleen and testis. It would appear that the ingested processed glutamic acid may move to any glutamate receptors available to it and create an adverse or toxic reaction to these tissues (Soliman 2010). Sodium Metabisulfite (SMB) is most commonly used as a preservative in food products, such as biscuits, chocolate, jam, sausage and salami, in many alcoholic beverages such as beer wine, champagne etc. and in drugs such as parenteral amino acid solutions (Rencuzog ullari et al, 2001a). Sodium metabisulfite added to food for control of enzymatic and non- enzymatic browning, antimicrobial actions, antioxidant, reducing agent 
uses, and bleaching agent uses (Taylor et al, 1986). Sodium metabisulfite may act through cell disruption and compromise membrane permeability and lipid peroxidation (Derin et al., 2006). Ingested sulfite enters into the systemic circulation via gastrointestinal absorption and distributed essentially to all body tissues including the brain (Gunnison and Benton 1971). In the last few years, fear had increased due to the adverse reaction and toxicity of the Monosodium Glutamate (MSG) and Sodium Metabisulfite (SMB). So, the aim of the present study was designed to investigate the histopathological effects of MSG and SMB on different body organs as well as its effects on blood picture and function of vital body organs.

\section{MATERIALS AND METHODS}

In this study, 80 adult male albino rats (150-180 gm) were divided into 5 groups; treated as following: -G1: Control rats: given saline by stomach tube daily for 12 weeks. -G2: rats administrated $30 \mathrm{mg} \mathrm{MSG} / \mathrm{kg} \mathrm{B}$.Wt per os for 12 weeks. -G3: rats administrated $60 \mathrm{mg} \mathrm{MSG} / \mathrm{kg}$ B.Wt per os for 12 weeks. G4: rats administrated $260 \mathrm{mg}$ SMB $/ \mathrm{kg}$ B.Wt per os for 12 weeks. G5: rats administrated $520 \mathrm{mg} \mathrm{SMB} / \mathrm{kg} \mathrm{B}$.Wt per os for 12 weeks.

\subsection{Blood and serum samples:}

were collected after 2, 4, 8 and 12 weeks post administration for determination of $\mathrm{RBCs}, \mathrm{Hb}$, $\mathrm{PCV}, \mathrm{MCV}, \mathrm{MCH}, \mathrm{MCHC}$, Platelets and $\mathrm{WBCs}$ counts performed using HA-Vet Automatic Hematology analyzer (CLINDIAG SYSTEM). Total Protein (Weichselbum (1946), activities of AST, ALT (Hayashi et al; (2003), Albumin (Doumas et al; (1971), Creatinine (Fabiny and Ertingshausen (1971)) and Urea (Henry et al; (1974)) were determined in serum.

\subsection{Histopathological examination:}

Specimens were collected from Brain, Heart, Lung, Liver, Spleen, Stomach, Intestine, Kidneys and Testis after 2, 4, 8 and 12 weeks and preserved in neutral buffer formalin solution (10\%) for histopathological examination according to Banchroft et al., (1996).

\subsection{Statistical analysis:}

The data obtained were analyzed statistically using one-way analysis of variance (ANOVA) with $P<0.05$ (the level of significance).

\subsection{Hematological and Serological Examination:}

Data demonstrating the effect of MSG administration on erythrogram parameters, total leukocytic counts, platelets counts, serum ALT (GPT), AST (GOT), blood urea nitrogen, creatinine, serum total protein and albumin at 2, 4, 8 and 12weeks post administration were summarized in table (1, 2, 3 and 4).

\subsection{Histopathological Examination:}

\subsubsection{MonoSodium Glutamate:}

Our results revealed that MSG by a dose of 30 $\mathrm{mg} / \mathrm{kg} \mathrm{b.wt}$ and $60 \mathrm{mg} / \mathrm{kg}$ b.wt showed mild to severe adverse effect on the body organs included congestion in liver, lung, testes, brain and kidney with the presence of grayish white foci on cutting surface of liver and kidney, atrophy of the testes and heart showed presence of petechial and grayish streaks on the heart surfaces.

MSG by a dose of $30 \mathrm{mg} / \mathrm{kg} \quad$ b.wt microscopically, the liver showed congestion and degenerative changes in hepatocytes. Presence of eosinophilic debris in the bronchial lumina and peribronchial leukocytic infiltrations. Testes showed intertubular edema, degenerative changes and necrosis of the epithelial cell lining of the seminiferous tubules. Brain showed congestion of meningeal and brain blood vessels with focal small area of malacia. Kidney showed mild congestion of the renal blood vessels, renal tubules showed mild degenerative changes with presence of eosinophilic debris in their Lumina.

Stomach showed leukocytic infiltration in the lamina propria, intestine showed mild degenerative changes in the epithelial lining of the intestinal villi with leukocytic infiltration in the lamina propria. Heart showed small focal areas of hyalinosis in the cardiac muscle and focal areas of intermuscular hemorrhage. Meanwhile, at dose $60 \mathrm{mg} / \mathrm{kg}$ b.wt of MSG the liver showed severe degree of hydropic degeneration of the hepatocytes and Periductal fibrosis.

Thrombus formation in the pulmonary blood vessels and the bronchioles showed desquamation of their epithelial cell lining with the presence of eosinophilic debris in their luminae. Testes showed thrombosis of most of testicular blood vessels, degenerative changes of the seminiferous tubules and atrophy of the testicular tissue with complete degeneration of the epithelial cells lining the seminiferous tubules. Tygrolysis of most of neurons with Focal areas of hemorrhages.

\section{RESULTS}




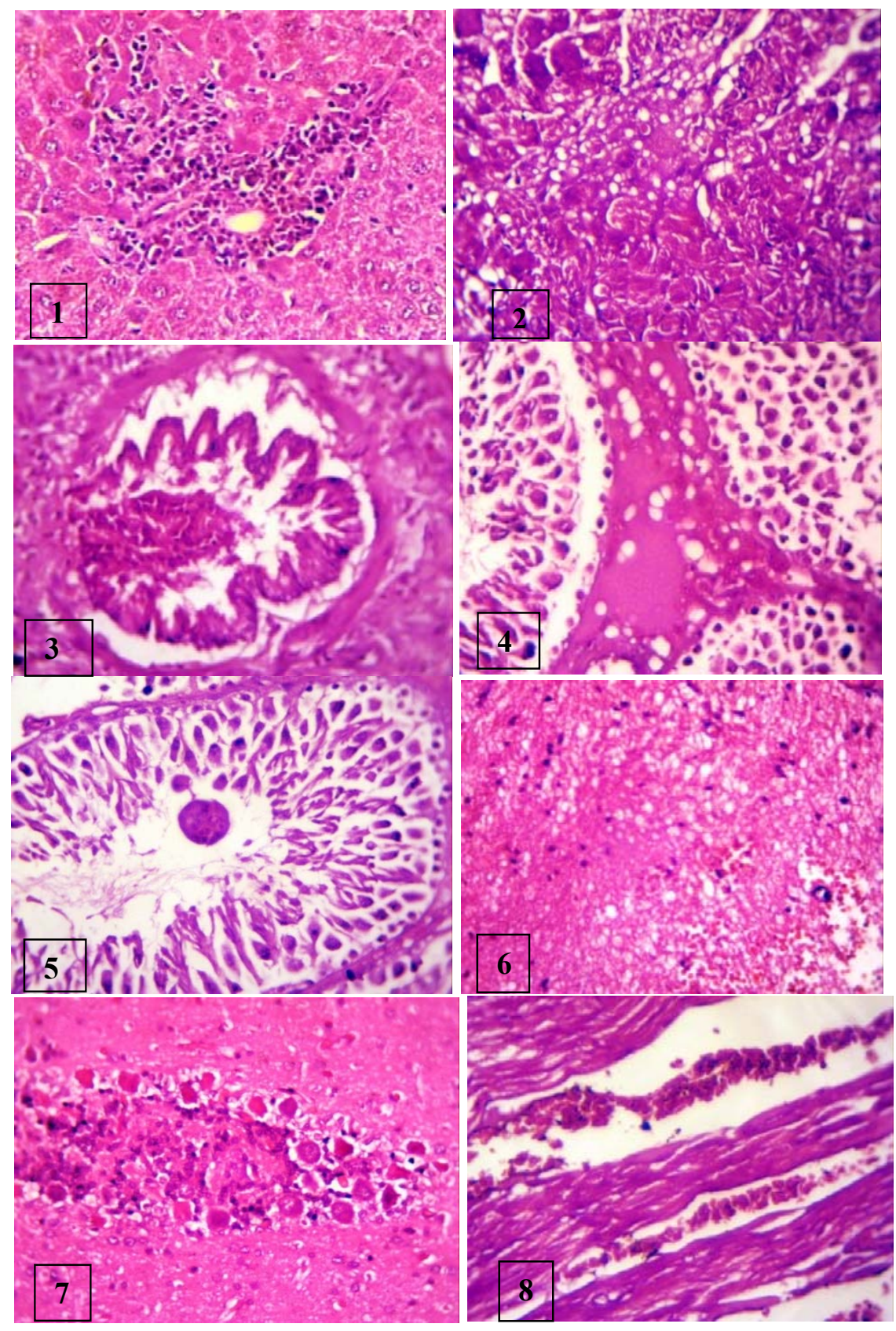

Fig. (1): Liver of rat received a dose of MSG 30mg/kg b.wt for 2 weeks showing mononuclear leukocytic infiltration in the portal area. (H\&E. X400). Fig. (2): Liver of rat received a dose of MSG 30mg $/ \mathrm{kg}$ b.wt for 4 weeks showing the presence of clear vacuoles in the cytoplasm of the hepatocytes which displaced the nucleus in one side. (H\&E. X400). Fig. (3): Lung of rat received a dose of MSG 30mg/kg b.wt for 12 weeks showing severe desquamation and slaughing of the epithelial lining the bronchioles. (H\&E. X800). Fig. (4): Testes of rat received a dose of MSG $30 \mathrm{mg} / \mathrm{kg}$ b.wt for 2 weeks showing presence of homogenous eosinophilic substances in between the seminiferous tubules. (H\&E. X800). Fig. (5): Testes of rat received a dose of MSG $30 \mathrm{mg} / \mathrm{kg}$ b.wt for 12 weeks showing presence sperm giant cell in the tubular lumen. (H\&E. X800). Fig. (6): Brain of rat received a dose of MSG $30 \mathrm{mg} / \mathrm{kg}$ b.wt for 8 weeks showing vacuolation of the brain substances. (H\&E. X200). Fig. (7): Brain of rat received a dose of MSG 30mg/kg b.wt for 12 weeks showing tygrolysis of the neurons of the purkinje cell layers of the cerebellum. (H\&E. X200). Fig. (8): Heart of rat received a dose of MSG 30mg/kg b.wt for 12 weeks showing intermuscular hemorrhage. (H\&E. X800). 




Fig. (9): Kidney of rat received a dose of MSG $30 \mathrm{mg} / \mathrm{kg}$ b.wt for 4 weeks showing intertubular mononuclear leukocytic infiltration.(H\&E. X600). Fig. (10): Liver of rat received a dose of MSG $60 \mathrm{mg} / \mathrm{kg}$ b.wt for 8 weeks showing focal leukocytic aggregation in the portal area. (H\&E. X400). Fig. (11): Testes of rat received a dose of MSG $60 \mathrm{mg} / \mathrm{kg}$ b.wt for 8 weeks showing complete atrophy of the seminiferous tubules.(H\&E. X600). Fig. (12): High power of the previous figure showing complete degeneration of the epithelial cell lining of the seminiferous tubules with increase amount of the interstitial tissue. (H\&E. X800). Fig. (13): Brain of rat received a dose of MSG $60 \mathrm{mg} / \mathrm{kg}$ b.wt for 12 weeks showing tygrolysis of some of neurons in the brain tissue. (H\&E. X800). Fig. (14): Kidney of rat received a dose of MSG $60 \mathrm{mg} / \mathrm{kg}$ b.wt for 12 weeks showing periglomerular and interstitial leukocytic infiltration. (H\&E. X200). Fig. (15): Lung of rat received a dose of SMB $260 \mathrm{mg} / \mathrm{kg}$ b.wt for 4 weeks showing focal leukocytic aggregation in the lung tissue. (H\&E. X400). Fig. (16): Kidney of rat received a dose of SMB $260 \mathrm{mg} / \mathrm{kg}$ b.wt for 4 weeks showing Focal leukocytic aggregations in the renal cortex. (H\&E. X800). 


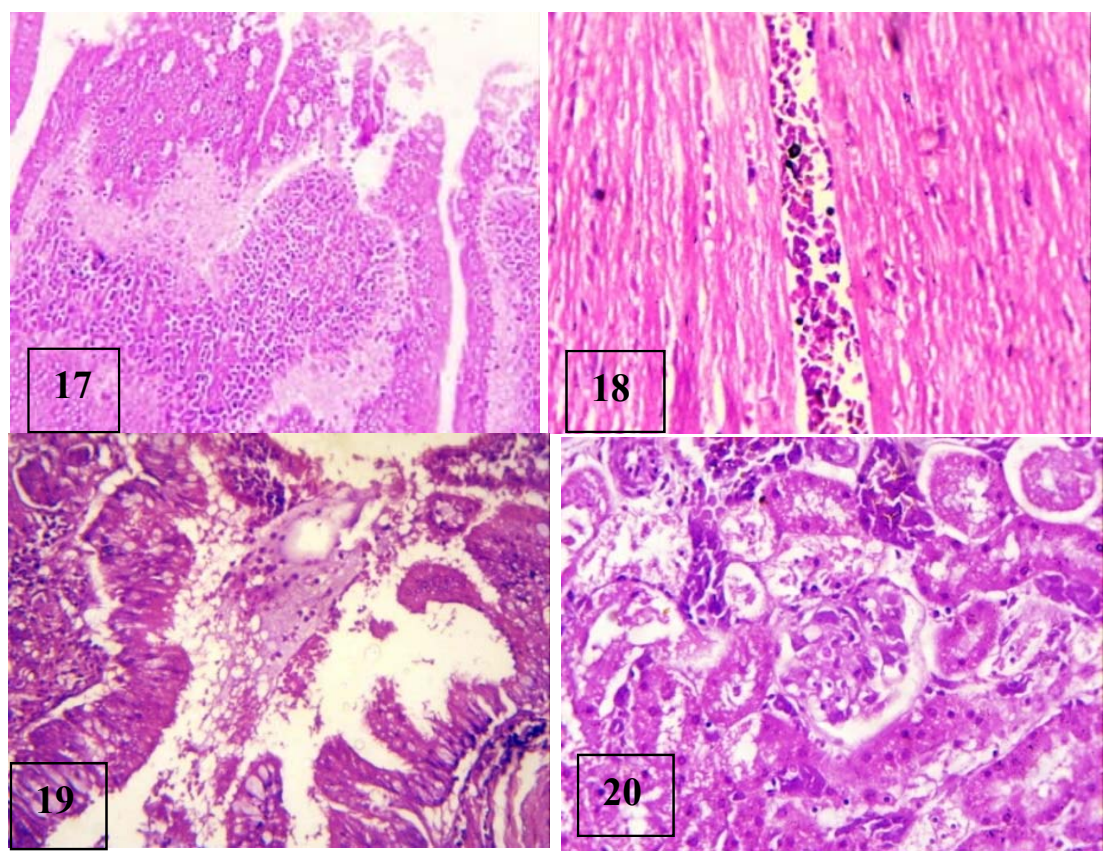

Fig. (17): Intestine of rat received a dose of SMB $260 \mathrm{mg} / \mathrm{kg}$ b.wt for 2 weeks showing necrotic changes with heavy leukocytic infiltration in the intestinal villi. (H\&E. X600). Fig. (18): Heart of rat received a dose of SMB $260 \mathrm{mg} / \mathrm{kg}$ b.wt for 4 weeks showing intermuscular hemorrhage. (H\&E. X800). Fig. (19): Lung of rat received a dose of SMB $520 \mathrm{mg} / \mathrm{kg}$ b.wt for 12 weeks showing severe degree of hyperplasia and desquamation of the epithelial lining of the bronchiole with presence of desquamated epithelial lining mixed with leukocytes in their lumen.(H\&E. X800). Fig. (20): Kidney of rat received a dose of SMB 520mg/kg b.wt for 2 weeks showing complete degeneration in the glomeruli and renal tubules. (H\&E. X800).

Table (1): RBCs, Hb, PCV, MCV, MCH, MCHC, Platelets, WBCs counts, Total Protein, Albumin, GOT, GPT, BUN and Creatinine at 2 weeks after a doses of MSG and SMB administrated orally by stomach tube in male Albino rats compared with their corresponding control groups. Results are expressed as mean \pm S.E.M $(\mathrm{N}=3: 4)$. Different superscript letters showing significance difference between control and other groups at $p \leq 0.05$.

\begin{tabular}{llllll}
\hline & Control & MSG 30 mg & MSG 60 mg & SMB 260 mg & SMB 520 mg \\
\hline RBCs $\left(\times 10^{6} / \mu \mathrm{l}\right)$ & $6.85 \pm 0.18^{\mathrm{b}}$ & $6.54 \pm 0.21^{\mathrm{b}}$ & $7.48 \pm 0.20^{\mathrm{a}}$ & $6.46 \pm 0.12^{\mathrm{b}}$ & $6.4 \pm 0.13^{\mathrm{b}}$ \\
$\mathrm{Hb}(\mathrm{g} / \mathrm{dl})$ & $13.35 \pm 0.49^{\mathrm{ab}}$ & $11.18 \pm 0.34^{\mathrm{c}}$ & $13.85 \pm 0.38^{\mathrm{a}}$ & $11.98 \pm 0.32^{\mathrm{c}}$ & $12.27 \pm 0.4^{\mathrm{bc}}$ \\
PCV $(\%)$ & $36.75 \pm 1.77^{\mathrm{ab}}$ & $32.02 \pm 1.13^{\mathrm{c}}$ & $39.30 \pm 1.30^{\mathrm{a}}$ & $34.42 \pm 1.44^{\mathrm{bc}}$ & $33.60 \pm 1.37^{\mathrm{bc}}$ \\
MCV(fl) & $53.60 \pm 1.64^{\mathrm{a}}$ & $49.03 \pm 1.54^{\mathrm{b}}$ & $52.52 \pm 0.63^{\mathrm{ab}}$ & $53.23 \pm 1.38^{\mathrm{ab}}$ & $52.40 \pm 1.20^{\mathrm{ab}}$ \\
MCH $(\mathrm{pg})$ & $19.52 \pm 0.58^{\mathrm{a}}$ & $17.10 \pm 0.41^{\mathrm{b}}$ & $18.50 \pm 0.22^{\mathrm{a}}$ & $19.15 \pm 0.47^{\mathrm{a}}$ & $18.83 \pm 0.45^{\mathrm{a}}$ \\
MCHC $(\%)$ & $36.40 \pm 0.79^{\mathrm{a}}$ & $34.90 \pm 0.25^{\mathrm{a}}$ & $35.27 \pm 0.35^{\mathrm{a}}$ & $36.0 \pm 0.69^{\mathrm{a}}$ & $35.90 \pm 0.04^{\mathrm{a}}$ \\
Platelets $\left(\times 10^{3} / \mu \mathrm{l}\right)$ & $654.75 \pm 44.24^{\mathrm{a}}$ & $834 \pm 60.97^{\mathrm{a}}$ & $636.5 \pm 90.46^{\mathrm{a}}$ & $655.5 \pm 79.21^{\mathrm{a}}$ & $698.66 \pm 27.22$ \\
& & & & & \\
WBCs $\left(\times 10^{3} / \mu \mathrm{l}\right)$ & $10.82 \pm 1.32^{\mathrm{b}}$ & $10.3 \pm 1.27^{\mathrm{b}}$ & $15.47 \pm 2.55^{\mathrm{ab}}$ & $16.37 \pm 1.74^{\mathrm{a}}$ & $14.6 \pm 1.06^{\mathrm{ab}}$ \\
T. protein $(\mathrm{g} / \mathrm{dl})$ & $7.45 \pm 0.58^{\mathrm{a}}$ & $9.35 \pm .34^{\mathrm{a}}$ & $9.35 \pm 0.92^{\mathrm{a}}$ & $8.98 \pm 1.18^{\mathrm{a}}$ & $8.85 \pm 0.41^{\mathrm{a}}$ \\
Albumin $(\mathrm{g} / \mathrm{dl})$ & $4.59 \pm 0.21^{\mathrm{ab}}$ & $3.80 \pm 0.32^{\mathrm{b}}$ & $4.93 \pm 0.53^{\mathrm{a}}$ & $3.67 \pm 0.31^{\mathrm{b}}$ & $4.86 \pm 0.20^{\mathrm{a}}$ \\
GOT $(\mathrm{U} / \mathrm{L})$ & $228.90 \pm 1.22^{\mathrm{b}}$ & $283.75 \pm 21.54^{\mathrm{ab}}$ & $317.35 \pm 23.15^{\mathrm{a}}$ & $307.43 \pm 35.44^{\mathrm{a}}$ & $233.23 \pm 8.31^{\mathrm{b}}$ \\
GPT $(\mathrm{U} / \mathrm{L})$ & $58.65 \pm 2.90^{\mathrm{b}}$ & $89.30 \pm 7.55^{\mathrm{ab}}$ & $116.34 \pm 22.57^{\mathrm{a}}$ & $114.79 \pm 8.15^{\mathrm{a}}$ & $57.44 \pm 0.35^{\mathrm{b}}$ \\
BUN $(\mathrm{mg} / \mathrm{dl})$ & $62.16 \pm 2.32^{\mathrm{b}}$ & $75.86 \pm 6.17_{\mathrm{ab}}$ & $81.45 \pm 4.01^{\mathrm{a}}$ & $66.07 \pm 8.86^{\mathrm{ab}}$ & $44.26 \pm 4.97^{\mathrm{c}}$ \\
Creatinine $(\mathrm{mg} / \mathrm{dl})$ & $0.51 \pm 0.07^{\mathrm{ab}}$ & $0.57 \pm 0.07^{\mathrm{ab}}$ & $0.53 \pm 0.06^{\mathrm{ab}}$ & $0.64 \pm 0.07^{\mathrm{a}}$ & $0.40 \pm 0.07^{\mathrm{b}}$ \\
\hline
\end{tabular}


Table (2): RBCs, Hb, PCV, MCV, MCH, MCHC, Platelets, WBCs counts, Total Protein, Albumin, GOT, GPT, BUN and Creatinine at 4 weeks after a doses of MSG and SMB administrated orally by stomach tube in male Albino rats compared with their corresponding control groups. Results are expressed as mean \pm S.E.M $(\mathrm{N}=3: 4)$. Different superscript letters showing significance difference between control and other groups at $p \leq 0.05$.

\begin{tabular}{|c|c|c|c|c|c|}
\hline & Control & MSG $30 \mathrm{mg}$ & MSG $60 \mathrm{mg}$ & SMB $260 \mathrm{mg}$ & SMB $520 \mathrm{mg}$ \\
\hline $\operatorname{RBCs}\left(\times 10^{6} / \mu \mathrm{l}\right)$ & $7.24 \pm 0.11^{\mathrm{a}}$ & $7.08 \pm 0.26^{\mathrm{a}}$ & $7 \pm 0.1^{\mathrm{a}}$ & $6.9 \pm 0.18^{\mathrm{a}}$ & $6.94 \pm 0.27^{\mathrm{a}}$ \\
\hline $\mathrm{Hb}(\mathrm{g} / \mathrm{dl})$ & $12.33 \pm 0.25^{\mathrm{a}}$ & $11.08 \pm 0.21^{\mathrm{a}}$ & $11.90 \pm 0.21^{\mathrm{a}}$ & $11.97 \pm 0.31^{\mathrm{a}}$ & $11.73 \pm 0.80^{\mathrm{a}}$ \\
\hline PCV (\%) & $37.97 \pm 0.63^{\mathrm{a}}$ & $35.07 \pm 1.08^{\mathrm{a}}$ & $37.85 \pm 0.1^{\mathrm{a}}$ & $38.30 \pm 1.14^{\mathrm{a}}$ & $38.25 \pm 2.72^{\mathrm{a}}$ \\
\hline MCV (fl) & $52.47 \pm 0.67^{\mathrm{ab}}$ & $49.55 \pm 1.04^{b}$ & $54.03 \pm 0.79^{a}$ & $55.47 \pm 0.1^{\mathrm{a}}$ & $54.88 \pm 1.76^{\mathrm{a}}$ \\
\hline MCH (pg) & $17.02 \pm 0.35^{\mathrm{a}}$ & $15.65 \pm 0.41^{\mathrm{b}}$ & $16.98 \pm 0.20^{\mathrm{a}}$ & $17.35 \pm 0.17^{\mathrm{a}}$ & $16.85 \pm 0.58^{\mathrm{a}}$ \\
\hline $\mathrm{MCHC}(\%)$ & $32.43 \pm 0.29^{\mathrm{a}}$ & $31.62 \pm 0.51^{\mathrm{ab}}$ & $31.48 \pm 0.34^{\mathrm{ab}}$ & $31.33 \pm 0.49^{\mathrm{ab}}$ & $30.7 \pm 0.73^{b}$ \\
\hline Platelets $\left(\times 10^{3} / \mu 1\right)$ & $512 \pm 71.61^{\mathrm{b}}$ & $746.75 \pm 70.41^{\mathrm{a}}$ & $793.5 \pm 42.35^{\mathrm{a}}$ & $434 \pm 76.39^{\mathrm{b}}$ & $615.5 \pm 41.55^{\mathrm{ab}}$ \\
\hline WBCs $\left(\times 10^{3} / \mu \mathrm{l}\right)$ & $12.62 \pm 2.16^{\mathrm{a}}$ & $11.87 \pm 1.02^{\mathrm{a}}$ & $15.47 \pm 3.45^{\mathrm{a}}$ & $17.22 \pm 1.34^{\mathrm{a}}$ & $16.57 \pm 7.47^{\mathrm{a}}$ \\
\hline T. protein $(\mathrm{g} / \mathrm{dl})$ & $8.14 \pm 0.32^{\mathrm{a}}$ & $7.24 \pm 0.54^{\mathrm{a}}$ & $7.11 \pm 0.32^{\mathrm{a}}$ & $7.65 \pm 0.17^{\mathrm{a}}$ & $8.19 \pm 0.28^{a}$ \\
\hline Albumin (g/dl) & $5.32 \pm 0.30^{\mathrm{b}}$ & $4.95 \pm 0.23^{b}$ & $5.14 \pm 0.61^{b}$ & $6.61 \pm 0.49^{\mathrm{a}}$ & $4.74 \pm 0.27^{\mathrm{b}}$ \\
\hline GOT (U/L) & $136.1 \pm 3.81^{\mathrm{c}}$ & $200.20 \pm 19.75^{b}$ & $192.70 \pm 10.11^{\mathrm{b}}$ & $219.68 \pm 16.21^{\mathrm{b}}$ & $269.87 \pm 19.10^{a}$ \\
\hline GPT (U/L) & $65.42 \pm 4.73^{c}$ & $70.72 \pm 4.95^{\mathrm{c}}$ & $88.40 \pm 0.72^{b c}$ & $98.80 \pm 14.61^{b}$ & $133.98 \pm 5.46^{\mathrm{a}}$ \\
\hline BUN (mg/dl) & $22.04 \pm 2.64^{\mathrm{c}}$ & $32.55 \pm 2.89^{b}$ & $36.26 \pm 1.36^{\mathrm{ab}}$ & $42.49 \pm 1.72^{\mathrm{a}}$ & $38.46 \pm 2.4^{\mathrm{ab}}$ \\
\hline Creatinine(mg/dl) & $0.43 \pm 0.01^{\mathrm{b}}$ & $0.84 \pm 0.06^{\mathrm{a}}$ & $0.68 \pm 0.05^{\mathrm{ab}}$ & $0.91 \pm 0.09^{\mathrm{a}}$ & $1.03 \pm 0.22^{\mathrm{a}}$ \\
\hline
\end{tabular}

Table (3): RBCs, Hb, PCV, MCV, MCH, MCHC, Platelets, WBCs counts, Total Protein, Albumin, GOT, GPT, BUN and Creatinine at 8 weeks after a doses of MSG and SMB administrated orally by stomach tube in male Albino rats compared with their corresponding control groups. Results are expressed as mean \pm S.E.M $(\mathrm{N}=3: 4)$. Different superscript letters showing significance difference between control and other groups at $p \leq 0.05$.

\begin{tabular}{|c|c|c|c|c|c|}
\hline & Control & MSG $30 \mathrm{mg}$ & MSG $60 \mathrm{mg}$ & SMB $260 \mathrm{mg}$ & SMB $520 \mathrm{mg}$ \\
\hline $\operatorname{RBCs}\left(\times 10^{6} / \mu \mathrm{l}\right)$ & $6.86 \pm 0.39^{\mathrm{a}}$ & $6.18 \pm 0.20^{\mathrm{a}}$ & $6.98 \pm 0.23^{\mathrm{a}}$ & $6.97 \pm .44^{\mathrm{a}}$ & $6.79 \pm 0.32^{\mathrm{a}}$ \\
\hline $\mathrm{Hb}(\mathrm{g} / \mathrm{dl})$ & $13.45 \pm 0.55^{\mathrm{a}}$ & $12.62 \pm 0.50^{\mathrm{a}}$ & $13.65 \pm 0.10^{\mathrm{a}}$ & $14 \pm 0.24^{\mathrm{a}}$ & $13.48 \pm 0.55^{\mathrm{a}}$ \\
\hline $\operatorname{PCV}(\%)$ & $38.93 \pm 1.86^{\mathrm{a}}$ & $37.18 \pm 1.09^{\mathrm{a}}$ & $38.43 \pm 1.07^{\mathrm{a}}$ & $38.20 \pm 1.96^{\mathrm{a}}$ & $38.88 \pm 1.69^{\mathrm{a}}$ \\
\hline $\operatorname{MCV}(\mathrm{fl})$ & $56.88 \pm 0.50^{\mathrm{ab}}$ & $60.30 \pm 2.08^{\mathrm{a}}$ & $55.13 \pm 1.27^{\mathrm{b}}$ & $55.05 \pm 2.39^{\mathrm{b}}$ & $57.23 \pm 0.45^{\mathrm{ab}}$ \\
\hline $\mathrm{MCH}(\mathrm{pg})$ & $19.70 \pm 0.56^{\mathrm{a}}$ & $20.50 \pm 0.98^{\mathrm{a}}$ & $19.63 \pm 0.56^{\mathrm{a}}$ & $20.35 \pm 1.46^{\mathrm{a}}$ & $19.85 \pm 0.25^{\mathrm{a}}$ \\
\hline $\mathrm{MCHC}(\%)$ & $34.60 \pm 0.80^{\mathrm{a}}$ & $33.95 \pm .52^{\mathrm{a}}$ & $35.60 \pm 0.73^{\mathrm{a}}$ & $36.98 \pm 2.35^{\mathrm{a}}$ & $34.70 \pm 0.16^{\mathrm{a}}$ \\
\hline Platelets $\left(\times 10^{3} / \mu 1\right)$ & $365.25 \pm 54.73^{\mathrm{a}}$ & $492.25 \pm 140.1^{\mathrm{a}}$ & $498 \pm 112.2^{\mathrm{a}}$ & $533.75 \pm 117.28^{\mathrm{a}}$ & $580.25 \pm 54.07^{\mathrm{a}}$ \\
\hline $\operatorname{WBCs}\left(\times 10^{3} / \mu \mathrm{l}\right)$ & $12.72 \pm 0.89^{\mathrm{b}}$ & $18.32 \pm 2.49^{\mathrm{a}}$ & $15.92 \pm 0.74^{\mathrm{ab}}$ & $14.2 \pm 0.99^{\mathrm{ab}}$ & $14.85 \pm 2.35^{\mathrm{ab}}$ \\
\hline T. protein $(\mathrm{g} / \mathrm{dl})$ & $9.23 \pm 0.60^{\mathrm{a}}$ & $9.27 \pm 0.63^{\mathrm{a}}$ & $10.42 \pm 0.72^{\mathrm{a}}$ & $8.90 \pm 0.69^{\mathrm{a}}$ & $9.44 \pm 0.68^{\mathrm{a}}$ \\
\hline $\operatorname{Albumin}(\mathrm{g} / \mathrm{dl})$ & $3.81 \pm 0.25^{\mathrm{a}}$ & $3.82 \pm 0.17^{\mathrm{a}}$ & $3.92 \pm 0.17^{\mathrm{a}}$ & $3.88 \pm 0.30^{\mathrm{a}}$ & $3.59 \pm 0.14^{\mathrm{a}}$ \\
\hline GOT(U/L) & $157.65 \pm 11.43^{\mathrm{ab}}$ & $206.85 \pm 19.17^{\mathrm{a}}$ & $171.50 \pm 10.01^{\mathrm{ab}}$ & $210.40 \pm 36.67^{\mathrm{a}}$ & $132.15 \pm 14.46^{\mathrm{b}}$ \\
\hline GPT(U/L) & $69.81 \pm 4.36^{\mathrm{ab}}$ & $72.49 \pm 9.97^{\mathrm{ab}}$ & $74.26 \pm 0.72^{\mathrm{ab}}$ & $81.78 \pm 8.94^{\mathrm{a}}$ & $58.79 \pm 6.05^{\mathrm{b}}$ \\
\hline BUN(mg/dl) & $14.61 \pm 2.30^{\mathrm{c}}$ & $24.56 \pm 4.02^{\mathrm{bc}}$ & $28.60 \pm 3.65^{\mathrm{b}}$ & $43.27 \pm 5.76^{\mathrm{a}}$ & $35.38 \pm 4.62^{\mathrm{ab}}$ \\
\hline Creatinine $(\mathrm{mg} / \mathrm{dl})$ & $0.56 \pm 0.12^{\mathrm{b}}$ & $1.51 \pm 0.23^{\mathrm{a}}$ & $1.47 \pm 0.17^{\mathrm{a}}$ & $1.31 \pm 0.23^{\mathrm{a}}$ & $1.33 \pm 0.16^{\mathrm{a}}$ \\
\hline
\end{tabular}


Table (4): RBCs, Hb, PCV, MCV, MCH, MCHC, Platelets, WBCs counts, Total Protein, Albumin, GOT, GPT, BUN and Creatinine at 12 weeks after a doses of MSG and SMB administrated orally by stomach tube in male Albino rats compared with their corresponding control groups. Results are expressed as mean \pm S.E.M $(\mathrm{N}=3: 4)$. Different superscript letters showing significance difference between control and other groups at $p \leq 0.05$.

\begin{tabular}{lccccc}
\hline & Control & MSG 30 mg & MSG 60 mg & SMB 260 mg & SMB 520 mg \\
\hline RBCs $\left(\times 10^{6} / \mu 1\right)$ & $6.95 \pm 0.24^{\mathrm{a}}$ & $7.35 \pm 0.28^{\mathrm{a}}$ & $7.59 \pm 0.33^{\mathrm{a}}$ & $7.68 \pm 0.16^{\mathrm{a}}$ & $7.01 \pm 0.18^{\mathrm{a}}$ \\
$\mathrm{Hb}(\mathrm{g} / \mathrm{dl})$ & $12.10 \pm 0.12^{\mathrm{b}}$ & $13.60 \pm 0.56^{\mathrm{a}}$ & $13.83 \pm 0.37^{\mathrm{a}}$ & $13.95 \pm 0.36^{\mathrm{a}}$ & $13.97 \pm 0.17^{\mathrm{a}}$ \\
$\mathrm{PCV}(\%)$ & $37.03 \pm 0.46^{\mathrm{b}}$ & $39.75 \pm 1.80^{\mathrm{ab}}$ & $39.50 \pm 0.70^{\mathrm{ab}}$ & $41.48 \pm 1.20^{\mathrm{a}}$ & $38.57 \pm 1.26^{\mathrm{ab}}$ \\
$\mathrm{MCV}(\mathrm{fl})$ & $53.45 \pm 1.4^{\mathrm{a}}$ & $54.05 \pm 1.53^{\mathrm{a}}$ & $52.33 \pm 1.73^{\mathrm{a}}$ & $54.03 \pm 1.19^{\mathrm{a}}$ & $55 \pm 0.51^{\mathrm{a}}$ \\
$\mathrm{MCH}(\mathrm{pg})$ & $17.48 \pm 0.68^{\mathrm{b}}$ & $18.50 \pm 0.39^{\mathrm{ab}}$ & $18.33 \pm 0.85^{\mathrm{ab}}$ & $18.18 \pm 0.28^{\mathrm{ab}}$ & $19.93 \pm 0.27^{\mathrm{a}}$ \\
MCHC$(\%)$ & $32.68 \pm 0.44^{\mathrm{c}}$ & $34.28 \pm 0.97^{\mathrm{abc}}$ & $35.03 \pm 0.54^{\mathrm{ab}}$ & $33.68 \pm 0.57^{\mathrm{bc}}$ & $36.33 \pm 0.81^{\mathrm{a}}$ \\
Platelets $\left(\times 10^{3} / \mu 1\right)$ & $503.25 \pm 80^{\mathrm{b}}$ & $731.75 \pm 55.62^{\mathrm{ab}}$ & $740.66 \pm 32.06^{\mathrm{ab}}$ & $596.5 \pm 124.55^{\mathrm{ab}}$ & $781 \pm 70.22^{\mathrm{a}}$ \\
WBCs $\left(\times 10^{3} / \mu \mathrm{l}\right)$ & $14.45 \pm 1.51^{\mathrm{a}}$ & $16.62 \pm 1.86^{\mathrm{a}}$ & $18.1 \pm 1.03^{\mathrm{a}}$ & $15.8 \pm 1.68^{\mathrm{a}}$ & $16.9 \pm 1.01^{\mathrm{a}}$ \\
T. protein $(\mathrm{g} / \mathrm{dl})$ & $7.94 \pm 0.24^{\mathrm{b}}$ & $13.45 \pm 1.60^{\mathrm{a}}$ & $7.74 \pm 1.38^{\mathrm{b}}$ & $8.30 \pm 1.15^{\mathrm{b}}$ & $5.46 \pm 1.54^{\mathrm{b}}$ \\
Albumin$(\mathrm{g} / \mathrm{dl})$ & $4.31 \pm 0.45^{\mathrm{a}}$ & $3.35 \pm 0.23^{\mathrm{ab}}$ & $4.30 \pm 0.14^{\mathrm{a}}$ & $4.2 \pm 0.07^{\mathrm{a}}$ & $4.46 \pm 0.65^{\mathrm{b}}$ \\
GOT(U/L) & $145.13 \pm 6.5^{\mathrm{b}}$ & $186.10 \pm 24.74^{\mathrm{ab}}$ & $210.97 \pm 25.33^{\mathrm{a}}$ & $231.60 \pm 24.03^{\mathrm{a}}$ & $229.27 \pm 7.12^{\mathrm{a}}$ \\
GPT(U/L) & $54.81 \pm 1.44^{\mathrm{b}}$ & $73.37 \pm 9.59^{\mathrm{ab}}$ & $66 \pm 8.67^{\mathrm{ab}}$ & $79.12 \pm 3.98^{\mathrm{a}}$ & $74.26 \pm 1.44^{\mathrm{ab}}$ \\
BUN(mg/dl) & $19.45 \pm 0.91^{\mathrm{b}}$ & $32.07 \pm 4.70^{\mathrm{a}}$ & $32.44 \pm 2.77^{\mathrm{a}}$ & $36.87 \pm 3.44^{\mathrm{a}}$ & $38.49 \pm 1.06^{\mathrm{a}}$ \\
Creatinine(mg/dl) & $0.33 \pm 0.02^{\mathrm{b}}$ & $0.75 \pm 0.02^{\mathrm{a}}$ & $0.74 \pm 0.05^{\mathrm{a}}$ & $0.77 \pm 0.04^{\mathrm{a}}$ & $0.69 \pm 0.02^{\mathrm{a}}$ \\
\hline
\end{tabular}

Kidney showed proliferation of the glomerular tufts, vacuolation of the glomerular tufts and in the epithelial lining of the renal tubules with mild cystic dilatation of renal tubules. Heart showed severe congestion of the cardiac blood vessels.

\subsubsection{SodiumMeta Bisulfite:}

Our results revealed that SMB by a dose $260 \mathrm{mg} / \mathrm{kg}$ b.wt and $520 \mathrm{mg} / \mathrm{kg}$ b.wt showed mild to severe adverse effect on the body organs included grayish white foci in the hepatic surface and kidney. The presence of dark red and brownish areas on lung surfaces. The testes become small in size with thickening capsules. The brain showed congestion of blood vessels. The intestine showed severe congestion of the intestinal mucosa and erosion.

SMB by a dose $260 \mathrm{mg} / \mathrm{kg}$ b.wt microscopically, the liver showed mild degree of vacuolar, hydropic degeneration and newly formed bile ductules. The pulmonary tissue showed perivascular leukocytic infiltration with focal leukocytic aggregation in lung tissue. Testes showed degenerative changes and necrosis in the germinal epithelium lining the seminiferous tubules with formation of sperm giant cell. Brain showed mild perivascular leukocytic infiltration and Focal areas of encephalomalacia. The kidneys showed that the renal medulla showed mild cystic dilatation with presence of hyaline cast in the lumen of the renal tubules. Intestine showed massive desquamation of their epithelial cell lining with heavy leukocytic infiltration. The heart showed intermuscular hemorrhage and myomalacia. The spleen showed lymphoid depletation and massive hemosidrosis.

Moreover at dose $520 \mathrm{mg} / \mathrm{kg}$ b.wt the portal areas showed heavy leukocytic aggregations (mononuclear type). The bronchioles showed severe degree of hyperplasia and desquamation of the epithelial lining. Testes showed severe degenerative changes of the epithelial cell lining of the seminiferous tubules. Tygrolysis in the neurons of the cerebellum in the granular cell layer. Degeneration in the glomeruli and renal tubules with periglomerular and intertubular mononuclear leukocytic infiltration. Intestine and gastric muocosa showed necrotic enteritis with heavy leukocytic infiltration in the lamina propria.

\section{DISCUSSION:}


In the present study rats treated with MSG showed a significant decrease in PCV, MCV values and $\mathrm{Hb}$ concentration of rats. These results agreed with Ashaolu et al. (2011) and Ibrahim et al. (2012); that might be mediated through a deleterious effect of MSG on the hemopoietic stem cells in the bone marrow. MSG might cause increased oxidative stress which induced the formation of micro nucleated polychromatic erythrocytes as reported by Farombi and Onyema (2006). GOT values showed a significant increase. These results agreed with Egbuonu et al. (2009), Egbuonu et al. (2010 a), Eweka et al. (2011) and Inuwa et al. (2011). These may be due to rats that were fed MSG, probably predicting damage to the liver and other organs with high metabolic activity (including the brain, heart and lungs) as previously reported by Bain (2003). In addition, the observed increase in the serum AST activity may be indicative of myocardial infarction as suggested by Rodwell and Kennelly (2003). A significant increase in BUN and creatinine values due to renal damage that cause increase in BUN and Creatinine were noticed. These results agreed with Egbuonu et al. (2010 c), Abass, and Abd El-Haleem (2011), Eraque (2011), Inuwa et al. (2011) and Tawfik, and Al-Badr, (2012). That may be due to Urea is the major nitrogen-containing metabolic product of protein catabolism.

The liver of rats received MSG showed mild proliferations of the fibrous connective tissue in the portal areas and severe vacuolar and hydropic degeneration of the hepatocytes. Moreover, focal areas of necrosis infiltrated with mononuclear cellular infiltration and various degree of hyperplasia of the bile duct were also noticed. The effects observed in the liver could have occurred because this organ involved in the metabolism of glutamate as reported by Collison (2009). Periductal fiberous tissue proliferations were also noticed. These results agreed with Wear and Edress (2006), Mohammed (2007), Egbuonu et al. (2010), Eweka et al. (2011), Al-Mosaibih (2013) and Onaolapo et al. (2013). The bronchioles showed mildest degree of catarrhal bronchiolitis with presence of eosinophilic debris in the lumen and focal areas of leukocytic aggregations. These results may be due to the toxic effects of MSG on blood vessels and lung tissue contains glutamate receptors which might be a target organ for MSG.

The testes of rats showed intertubular edema and increasing amount of leydig cells mixed with leukocytic infiltration. Moreover, the seminiferous tubules showing mild degenerative changes and apoptosis in the epithelial cell lining together with necrosis of the epithelial cell lining of these tubules and atrophy of the testicular tissue with complete degeneration of the epithelial cells lining the seminiferous tubules. These histological changes may be due to local effect of the chemical. Balasubramanian et al. (1980) explained the congestion of blood vessels as being due to the inhibition of prostaglandins synthesis, since these compounds are known to be involved in the regulation of testicular blood flow. Earlier studies proved the presence of functional glutamate transporters and receptors in testes of rats as reported by Gill et al, (2000), Takarada et al, (2004) and $\mathrm{Hu}$ et al, (2004) in mice, testes are considered as a target organ for MSG. So, one of the mechanisms may be a direct effect of MSG via glutamate receptors and transporters on the epithelial cells of the seminiferous tubules. The second mechanism was proved by other researchers Gong et al, (1995) and Giovambattista et al, (2003) who mentioned that there are neurotoxin effects of MSG on the function of hypothalamus-pituitary-gonadal system. The effects of such toxicants on male reproduction may be anatomical or only functional, depending on whether they produce structural changes in the reproductive system, or merely affect the functions of the reproductive organs as mentioned by Witorsch (1995). The third mechanism reported that exposure to MSG resulted in a decrease in the testicular ascorbic acid level that could lead to oxidative damage in rat testes as reported by Vinodini et al, (2010 a). These results agreed with Eweka and Om'Iniabohs (2008).

The brain of rats showed perivascular hemorrhages and thrombosis. Moreover, area of malacia scattered all over the brain tissue and tygrolysis. Demyelination of the axons of the nerve and mild edema around the neurons were also seen. These changes in the brain tissue may be due to excessive accumulation of glutamate in the synaptic cleft has been associated with excitotoxicity. Excitotoxicity is the pathological process by which nerve cells are damaged and killed by excessive stimulation by neurotransmitters such as glutamate and similar substances as previously mentioned by Mallick, (2007). These changes may be due to neurotoxicity of MSG is related with glutamate receptors activation. Such excessive activation of glutamate receptors and overloading with intracellular calcium can induce neural death as previously mentioned by Gil-Loyzaga et al., (1993). These findings agreed with Eweka and Om'Iniabohs (2007b), Hashem, et al. (2012) and Ibrahim et al. (2012). 
The glomeruli showed profilation and vacuolation of the glomerular tufts with mild thickening of the Bowmen's capsules. Many renal tubules and glomeruli of the rat kidneys showed marked degenerative lesions. These changes in the renal tissue may be returned to Tisher and Brenner, (1989) who postulated the degenerative effect of MSG on the kidney due to the effect of toxins on the cells of the kidney through transport mechanisms. Also the tubule came in contact with toxic chemicals during their excretion and elimination by the kidneys. Other mechanisms for the tubular lesions might involve reactive intermediates or oxidative stress, or both Alden and Frith, (1992) and Ebaid and Tag, (2012). These results agreed with Eweka (2007), Abass and Abd El-Haleem (2011), Eraque (2011), Afeefy et al. (2012), Onaolapo et al. (2013) and Dixit, et al. (2014) who postulated that the degenerative effect of MSG on the cortex and medulla of kidney was due to the direct effect of toxins on cells of kidney which coincided with (Porter, 1994) who reported that one of the possible mechanism for the tubular lesions was the direct toxic effect on the cell function.

In the present study, rats treated with SMB showed a significant decrease in the concentration of $\mathrm{Hb}$. These results agreed with El Kadi et al. (2014) and Mohamad (2011), a significant increase in the total leukocytic counts in group treated for 2 weeks, a significant increase in both GPT and GOT values. These results agreed with AlarcónCorredor et al. (2000) who reported that these findings indicate there are cellular damage to rat liver, kidney or others organs as a result of bisulphite injected or by its metabolic derivatives, Mohamad (2011) and El Kadi et al. (2014), significant $(P<0.05)$ increase in both BUN and creatinine values. These results may be due to Creatinine and urea is excellent markers of renal function, and their increase or decrease reflects a dysfunction of the renal function as reported by Sirwal, (2004). Significant $(P<0.05)$ increase in the albumin values. These results disagreed with Mohamad (2011) who found that Protein and albumin showed significant decrease in quantity during the experiment in the treatment groups compared to the control group.

Our results revealed that the liver of rats received SMB showed degenerative changes in the hepatocytes in our results may be due to the vacuolation of hepatocytes as ballooning degeneration and interpreted it as a kind of cellular defensive mechanism against injurious substances according to Abdel Hameed, (2004). The bile duct in the portal area showed mild to severe thickening in the wall due to fibrous tissue proliferation and newly formed bile ductules. Multiple areas of necrosis scattered in the hepatic parenchyma. Severe degeneration of the hepatocytes and the portal area showed mononuclear leukocytic infiltration. These results agreed with Hui et al. (1989). Focal leukocytic aggregations in the pulmonary tissue. The bronchioles showed severe degree of hyperplasia and desquamation of the epithelial lining with presence of desquamated epithelial lining mixed with leukocytes. These results agreed with Mohamad (2011).

The testes in our results showed the seminiferous tubules become small in size with narrow lumen and absence of the spermatogenesis in most of them and necrosis in the germinal epithelium lining the seminiferous tubules with formation of sperm giant cell. The mechanisms of sulfite-induced lipid peroxidation have been shown to involve $\mathrm{SO}^{2-}$ oxidation into a sulfite radical (SO3).The sulfite radical can subsequently react with molecular oxygen to form sulfite peroxy radical (SO3OO.) and a sulfate radical (SO4), which in turn reacts with lipids according to Elmas et al., (2005) and Ercan et al., (2010). Also, the one electron oxidation of bisulphate produces the sulfur trioxide radical anion, which reacts rapidly with molecular oxygen to form peroxyl radical. The free radicals generated can damage nucleic acids and induce mutation according to Meng, (2003) and Meng and Bai, (2004). These results agreed with Mohamad (2011) and Adebayo, and ADenuga (2012).

The brain showed tygrolysis and severe degree of encephalomalacia. Although the mechanism of sulfite toxicity on the central nervous system is not completely understood, sulfur- and oxygencentered free radicals may be responsible for this effect of sulfite according to Abedinzadeh (2001). Sulfite metabolism generates an intermediate product called sulfur trioxide radical that may act in some toxic effects of sulfite, including increment of lipid peroxidation, impairment of DNA synthesis, and destruction of amino acids according to Niknahad and O'Brien (2008). These results partially agreed with Karimfar, et al. (2014) who stated that the volume and number of neurons of deep cerebellar nuclei were evaluated in sodium metabisulfite-treated rats. The kidneys showed Proliferation and congestion of the glomerular tuft, the presence of hyaline cast in the lumen of the renal tubules and Periglomerular and intertubular 
mononuclear leukocyticbinfiltration. These results agreed with Mohamad (2011) and Akanji et al. (1993). These findings in a complete agreement with Balazs and Roepke (1966) and Ellis et al, (1973) who added that damage to the glomerulus and the proximal convoluted tubule of the kidney results in impairment of reabsorptive functions of the renal system, consequently leading to excretion of protein and enzyme activities into the urine. The kidney being an organ involved with very active transportation of molecules and ions across cell membranes requires alkaline phosphatase in large amounts. Loss of alkaline phosphatase activity following administration of metabisulphite will thus prevent adequate transportation of required ions and molecules across the cell membranes. This can consequently lead to starvation of renal cells.

The gastric muocosa showed severe congestion of the blood vessels in the tunica muscularis and heavy leukocytic infiltration in the lamina propria. These results partially agreed with Hui et al. (1989) who said that in the fore- and glandular stomachs included moderate hyperkeratosis of the forestomach and alterations of the fundic portion of the stomach. These results may be due to sulfite derivatives have been shown to generate oxidative stress in several investigations according to Baker et al., (2002), Ercan et al., (2010) and Meng, (2003). Intestine showed necrotic changes with heavy leukocytic infiltration which replaced the intestinal villi extended in the mucosa and muscularis and the intestinal villi suffering from massive desquamation with the presence of heavy leukocytic infiltration. Spleen showed lymphoid depletion in their lymphoid follicles and focal necrotic foci. These results partially agreed with Mohamad (2011) who said that spleen of rats showed focal areas of hemorrhages with extramedullary hematopoiesis.

In conclusion, the addition of MSG resulted in marked changes in brain and testes while, SMB lead to marked changes in gastrointestinal tract and brain. These changes are dose and time independent in MSG and dose independent only in SMB.

\section{REFERENCES}

Abass, M.A., Abd El-Haleem, M.R. 2011. Evaluation of Monosodium Glutamate Induced Neurotoxicity and Nephrotoxicity in Adult Male Albino Rats. J. Am. Sci. 7(8): 264-276.

Abedinzadeh, Z. 2001. Sulfur-centered reactive intermediates derived from the oxidation of sulfur compounds of biological interest.Can J Physiol Pharmacol 79:166-170.

Abdel Hameed, T.F. 2004. Light and electron microscopic studies on the effect of orally administered formalin on liver and kidney of guinea pig. J. Egy. Germ. Soci. Zoology C. Histology and Histochemistry, 45 (c):203224.

Adebayo, O.L. and ADenuga, G.A. 2012. Oxidative damage on the testes of adult rats by sodium metabisulfite (MBS). Int. J. Biol. Chem. Sci. 6(2): 738-744.

Afeefy, A.A. Mahmoud, M.S., Arafa, M.A.A. 2012. Effect of Honey on Monosodium Glutamate Induced Nephrotoxicity (Histological and Electron Microscopic Studies). J Am Sci. 8(1s):146-156.

Akanji, M.A., Olagoke, O.A., Oloyede, O.B. 1993. Effect of chronic consumption of metabisulphite on the intergrity of the rat kidney cellular system. Toxicology, 81(3), 173-179.

Alarcón-Corredor, O.M., Ramirez de Fernández, M., Bastardo de Castañeda,G., Silva, T., Alarcón, A.O. 2000. Changes in serum enzymes in rats treated with sodium bisulfite. Acta Cient Venez.51(4):257-63.

Alden, C.L., Frith, C.H. 1992. Urinary System. In: Handbook of Toxicologic Pathology. Hashek WM and Rousseaux CG eds., Academic Press, San Diego, CA. 316-79.

AL-Mosaibih, M.A. 2013. Effects of Monosodium Glutamate and Acrylamide on the Liver Tissue of Adult Wistar Rats. Life Sci J. 10(2s):35-42.

Arruda,N.J.; Filho,J.L.; Montenegro,M.C.; Arau'jo,A.N. and Silva,V.L. 2003. Simple and inexpensive flow L-glutamate determination using pumpkin tissue. J. Agricul. And Food Chemistry 51, 69456948.

Ashaolu, J.O., Ukwenya,V.O., Okonoboh, A.B., Ghazal, O.K., Jimoh, A.A.G. 2011. Effect of monosodium glutamate on hematological parameters in Wistar rats. International Journal of Medicine and Medical Sciences. 3(6): 219-222.

Bain, P.J, Latimer, K.S, Mahaffrey, E.A, Prasse, K.W., Duncan, 2003. Prasse's Veterinary Laboratory Medicine. Clin. Pathol. Fourth edn. Lowa State Press. 193-414.

Baker, M.T., Dehring, D.J., Gregerson, M.S. 2002. Sulfite supported lipid peroxidation in propofol emulsions. Anesthesiology 97, 1162-1167.

Balasubramanian, A., Manimekalai, S., Singh, A., Ramakrishnan, S. 1980. Short and long-term 
effect of aspirin on testes of albino rats: a histological and biochemical study. Indian J Exp Biol. 18:1408-10.

Balazs, T., Roepke, R.R. 1966. Lysozymuria induced in rats by nephrotoxic agents. Proc. Soc. Exp. Biol. Med., 123 (1966) 380.

Banchroft, D.J., Cook, C.H., Stirling, R.W., Turner, D.R. 1996. Manual of histopathological techniques and their diagnostic application. ( $3^{\text {rd }}$.ed.) Chuchill Livingston, Edinburg.

Collison, K.S., Maqbool, Z., Saleh, S.M., Inglis, A. Makhoul, N.J, Bakheet, R. 2009. Effect of dietary monosodium glutamate on trans-fatinduced nonalcoholic fatty liver disease. $\mathrm{J}$ Lipid Res,; 50(8):1521-37.

Derin, N., Yargicoglu, P., Aslan, M., Elmas, O., Agar, A., Aiciguzel, Y. 2006. The effect of sulfite and chronic restraint stress on the brain lipid peroxidation and antioxidant enzyme activities. Toxicol. Ind. Health. 22(6): 240-233.

Dixit, S.G., Rani, P., Anand, A., Khatri, K., Chauhan, R., Bharihoke, V. 2014. To study the effect of monosodium glutamate on histomorphometry of cortex of kidney in adult albino rats. Ren Fail; 36(2): 266-270.

Doumas, B.T., Watsn, W.A., Biggs, H.G. 1971. Albumin standards and the measurement of serum albumin with bromocresol green.Clin. Chim. Acta, 31(1):87-96.

Ebaid, H.M. and Tag, H.M. 2012. Monosodium Glutamate Toxic Effect on Spleen Structure and Potentiality of Recovery in Adult Albino Rats. Egypt. Acad. J. biolog. Sci., 4(1): 1-8.

Egbuonu, A.C.C., Obidoa, O., Ezeokonkwo, C.A., Ezeanyika, L.U.S., Ejikeme,P.M. 2009. Low dose oral administration of monosodium glutamate in male albino rats may be nephroprotective. Bio. Res., 7: 470473.

Egbuonu, A.C.C., Obidoa, O., Ezeokonkwo, C.A., Ezeanyika, L.U.S., Ejikeme, P.M. 2010. Hepatotoxic effects of low dose oral administration of monosodium glutamate in male albino rats. African Journal of Biotechnology. 8(13), 3031-3035.

Egbuonu, A.C.C., Ezeokonkwo, C.A., Ejikeme, P.M., Obidoa, O., Ezeanyika, L.U.S. 2010 a. Some biochemical effects of sub-acute oral administration of L-arginine on monosodium glutamate-fed wistar albino rats 2: Serum alkaline phosphatase, total acid phosphatase and aspartate aminotransferase activities. Asian J. Biochem., 5(2): 89-95.

Egbuonu, A.C.C., Obidoa, O., Ezeokonkwo, C.A., Ejikeme, P.M., Ezeanyika, L.U.S. 2010 c. Some biochemical effects of sub-acute oral administration of L-arginine on monosodium glutamate-fed Wistar albino rats 1: body weight changes, serum cholesterol, creatinine, and sodium ion concentrations. Toxicological \& Environmental Chemistry. 92, (7). 13311337.

EL- Kadi, F.Z., Bénali, A.I., Bénali, M., Belbraouet, S. 2014. Effect of Sodium Metabisulphite on Blood Metabolic Status of Wistar Rats. Food and Nutrition Sciences, 5, 1529-1537.

Ellis, B.G., Price, R.G., Topham, J.C. 1973. The effect of tubular damage by mercuric chloride on kidney function and some urinary enzymes in the dog. Chem.-Biol. Interact. 7(1973)101.

Elmas, O., Aslan, M., Cağlar, S., Derin, N., Agar, A., Alicigüzel, Y., Yargiçoğlu, P. 2005. The prooxidant effect of sodium metabisulfite in rat liver and kidney. Regul Toxicol Pharmacol. 42(1):77-82.

Eraque, H.M.A.E. 2011. Histological study on the effect of Monosodium Glutamate on the Renal Cortex of adult male albino rats.Faculty of medicine- Zagazeg University; Basic Medical Sciences.

Ercan, S., Ozturk, N., Celik-Ozenci, C., Gungor, N.E., Yargicoglu, P. 2010. Sodium metabisulfite induces lipid peroxidation and apoptosis in rat gastric tissue. Toxicol. Ind. Health, 26(7): 425-431.

Eweka, A.O., OmIniabohs, F.A.E. 2007b. Histological studies of the effects of monosodium glutamate on the cerebellum of adult Wistar rats. Internet J. Neurol., 8(2): 68-72.

Eweka, A.O., Om'Iniabohs, F.A.E. 2008. Histological Studies Of The Effects Of Monosodium Glutamate On The Testis Of Adult Wistar Rats. The Internet Journal of Neurology. 5 (2).

Eweka, A.O., Igbigbi, P.S., Ucheya,R.E. 2011. Histochemical Studies of the Effects of Monosodium Glutamate on the Liver of Adult Wistar Rats. Ann Med Health Sci Res. 1(1): 21-29.

Fabiny, D.L., Ertingshausen, G. 1971. Automated reaction-rate method for determination of serum creatinine. Clin. Chem. 17: 696-700. 
Farmobi, E.O., Onyema, O.O. 2006. Monosodium glutamate-induced oxidative damage and genotoxicity in the rat: Modulatory role of vitamin $\mathrm{C}$, vitamin $\mathrm{E}$ and quercetin. Hum.Exp.Toxicol. 25: 251-259.

Gill, S., Mueller, R., Mcguire, P., Pulido, O. 2000. Potential target sites in peripheral tissues for excitatory neurotransmission and excitotoxicity. Toxicol Pathol. 28:277-84.

Gil-Loyzaga, P., Hernandez-Ortiz, M.J., Rodriguez-Benito, T., Lasso de la Vega, M. 1993. Diltiazem protects against neurotoxicity induced by excitotoxic amino acids on cochlear afferent fibers. J. Otorhinolaryngol. Relat, 55: 211-215.

Giovambattista, A., Suescun, M., Nessralla, C., Franca, L., Spinedi, E., Calandra, R. 2003. Modulatory effects of leptin on leydig cell function of normal and hyperleptinemic rats. Neuroendocrinology. 78:270-9.

Gong, S.L., Xia, F.Q., Wei, J., Li, X.Y., Sun, T.H., Lu, Z. et al. 1995. Harmful effects of MSG on function of hypothalamus-pituitarytarget gland system. Biomed Environ Sci. $8: 310-7$

Gunnison, A.F., Benton, A.W. 1971. Sulfur dioxideSulfite. Interaction with mammalian serum and plasma. Arch Environ Health. 22:381-88.

Hashem, H. E., Safwat, M.D.E., Algaidi, S., 2012. The effect of monosodium glutamate on the cerebellar cortex of male albino rats and the protective role of vitamin $\mathrm{C}$ (histological and immunohistochemical study). Journal of Molecular Histology . 43( 2), 179-186.

Hayashi, H., Mizuguchi, H., Miyahara, I., Nakajima, Y., Hirotsu, K., Kagamiyama, H. 2003. Conformational change in aspartate aminotransferase on substrate binding induces strain in the catalytic group and enhances catalysis. J. Bio. Chem. 278(11): 9481-9488.

Henry, J.B., Todd, Sanford, Davidsohn, 1974. Clinical Diagnosis and Measurement by laboratory methods. $16^{\text {th }}$ ed; W. B. Saunders and co., Philadelphia PA. p260.

Hu, J., Yang, N., Ma, Y., Jiang, J., Zhang, J., Fei, J., Guo,L. 2004. Identification of glutamate transporters and receptors in mouse testis. Acta Pharmacol Sin. 25:366-71.

Hui, J.Y., Beery, J.T., Higley, N.A., Taylor, S.L. 1989. Comparative subchronic oral toxicity of sulphite and acetaldehyde hydroxysulphonate in rats. Food Chem. Toxicol., 27, 349-359.

Ibrahim, O.M.S., Abdulhamza, N.N., Abbass, H.K. 2012. Some Hematological and
Histological Impact of sub-acute exposure to Mono Sodium Glutamate in Mice. Proceeding of the Eleventh Veterinary Scientific Conference.127-131.

Inuwa, H.M., Aina, V.O., Baba Gabi, I. Aim ola, Leehman Ja'afaru. 2011. Determination of Nephrotoxicity and Hepatoxicity of Monosodium Glutamate (MSG) Consumption. British Journal of Pharmacology and Toxicology 2(3): 148153.

Karimfar, M.H., Noorafshan, A., RashidianiRashidabadi, A., Poostpasand, A., AsadiGolshan, R. 2014. Curcumin prevents the structural changes induced in the rats' deep cerebellar nuclei by sodium metabisulfite, a preservative agent. Asian Pac J Trop. 7(1): S301-S305.

Mahindru, S.N. 2004. Food Additives: Characteristics, Detection and stimation, McGraw-Hill, New Delhi.

Mallick, H.N. 2007. Understanding of glutamate safety in food and brain. Ind $\mathrm{J}$ Physiol Pharmacol., 51:216-234.

MengZ. 2003. Oxidative damage of sulfur dioxide on various organs of mice: sulfur dioxide is a systemic oxidative damage agent. Inhal. Toxicol., 15: 181-195.

MengZ, Bai, W. 2004. Oxidative damage of sulfur dioxide on testicles of mice. Environ. Res., 96: 298-304.

Mohammed, M.A. 2007. Effect of Food Additive (Monosodium Glutamate) Administration on some Organs of Male Albino Rats. Faculty of science- EL Minia University, Dep. of Zoology.

Moreno, G., Perello, M., Gaillardand, R.C., Spine, E. 2005. Orexin astimulates hypothalamic- pituitv- adrenal (HPA) axis function, but not food intake in the absence of full hypothalamic NPY- ergic activity. Endocrine, 26: 99- 106.

Niknahad, H., O’Brien, P.J. 2008. Mechanism of sulfite cytotoxicity in isolated rat hepatocytes. Chem. Bio. Int., 174: 147- 154.

Nwaopara, A.O., Odike, M.A.C., Inegbenebor, U., Nwaopara, S.O., Ewere, G.I. 2008a. A comparative study on the effects of excessive consumption of ginger, clove, red pepper and black pepper on the histology of the Kidney. Pak.J.Nutr., 7:287291.

Obaseiki-Ebor, E.E., McGhee, E. M., Shankel, D.M. 2003. Improved detection of genotoxic and mutagenic potentials of a food condiment A-One (monosodium glutamate). Presented at the Fouth 
International Conference of the Pan-African Environment Mutagen Socity (PAEMS) in Dar El Diafa- Ain Shams University, Cairo, Egypt, 2 -7 March: 63.

Onaolapo, A.Y., Onaolapo, O.J., Mosaku, T.J., Akanji, O.O., Abiodun, O. 2013. A Histological Study of the Hepatic and Renal Effects of Subchronic Low Dose Oral Monosodium Glutamate in Swiss Albino Mice. British Journal of Medicine \& Medical Research, 3(2): 294-306.

Porter, G.A. 1994. Urinary biomarkers and nephrotoxicity. Miner Electrolyte Metab. 20(4): 181-86.

Rencuzog ullari,E.; Kayraldiz,A. and ·Ila,H.B., et al. 2001a. The Cytogenetic Effects of Sodium Metabisulphite, a Food Preservative in Root Tip Cells of Allium cepa L., Turk. J Biol. 25. 361-370.

Rodwell, V.W., Kennelly, P.J. 2003. Enzymes: Mechanism of action In: Murray, R. K.; Granner, D.K.; Mayes, P.A. and Rodwell, V.W. ed Harper's Illustrated Biochemistry 26th edn Lange Medical Books/McGrawHill, New York. chap 7, 57.

Soliman, A.M. 2010. Extract of coelatura aegyptiaca, a freshwater clam, ameliorates hepatic oxidative stress induced by monosodium glutamate in rats. African J. of Pharmacy and Pharmacology, 5(3): 398408.

Takarada, T., Hinoi, E., Balcar, V., Taniura, H., Yoneda, Y. 2004. Possible expression of functional glutarnate transporters in the rat testis. J Endocrinol. 181:233-44.

Tawfik, M.S., Al-Badr, N. 2012. Adverse Effects of Monosodium Glutamate on Liver and
Kidney Functions in Adult Rats and Potential Protective Effect of Vitamins C and E. Food and Nutrition Sciences, 3, 651659.

Taylor, S.L., Higley, N.A., Bush, R.K. 1986. Sulfites in foods: uses, analytical methods, residues, fate, exposure assessment, metabolism, toxicity, and hypersensitivity. Adv Food Res. 30:1-76.

Tisher, C.C., Brenner, B.M. 1989. Structure and function of the glomerulus. In: Renal Pathology with Clinical and Functional Correlations, Philadelphia, J. P. Lippincott. 92-110.

Vinodini, N.A., Nayanatara, A., Damodar, G., Damodar, B., Ramaswamy, C.R., Shabarinath, Bhat MR. 2010 a. Effect of monosodium induced oxidative damage on rat testis. J Clin Med. 3:370-3.

Vinodini, N.A., Nayanatara, A.K., Ramaswamy, C., Anu, V.R., Rekha, D.K., Damadara, G.K., Ahamed, M.B., Shabarinath, R.B. 2010 b. "Study on Evaluation of Monosodium Glutamate Induced Oxidative Damage on Renal Tissue on Adult Wistar Rats," J Chinese Clin Med, 5: 3. 144-147.

Waer, H.F., Edrees, S. 2006. The Effect of Monosodium Glutamate (MSG) On Rat Liver and The Ameliorating Effect Of "Guanidino Ethane Sulfonic acid (GES)" (Histological, Histochemical and Electron Microscopy Studies) The Egyptian Journal of Hospital Medicine. 24: $524-538$.

Weichselbaum, T.E. 1946. An accurate and rapid method for the determination of proteins in small amounts of blood, serum and plasma. Am. J. Clin. Pathol. 10:40-49. 